
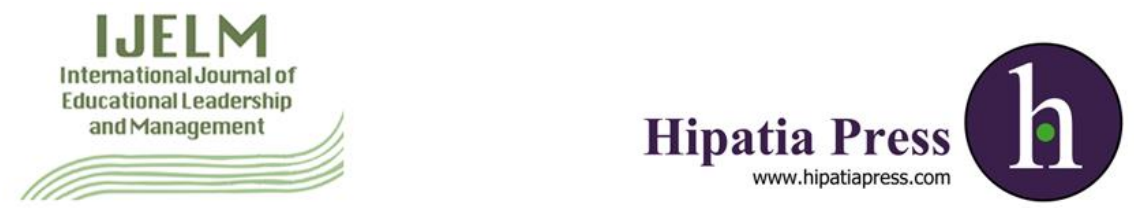

Instructions for authors, subscriptions and further details:

http://ijelm.hipatiapress.com

\title{
Investigating principals' knowledge and perceptions of second language programs for English language learners
}

Yolanda N. Padron ${ }^{1}$, Hersh C. Waxman ${ }^{1}$

1) Texas A \& M University. United States of America

Date of publication: July $16^{\text {th }}, 2016$

Edition period: July 2016-January 2017

To cite this article: Padron, Y. and Waxman, H.C. (2016). Investigating principals' knowledge and perceptions of second language programs for English language learners. International Journal of Educational Leadership and Management, 4(2), 127-146. doi: 10.17583/ijelm.2016.1706

To link this article: http://dx.doi.org/10.17583/ijelm.2016.1706

\section{PLEASE SCROLL DOWN FOR ARTICLE}

The terms and conditions of use are related to the Open Journal System and to Creative Commons Attribution License (CC-BY). 


\section{Investigating Principals' Knowledge and Perceptions of Second Language Programs for English Language Learners}

Yolanda N. Padron

Texas A \& M University
Hersh C. Waxman

Texas $A \& M$ University

\section{Abstract}

This study examined principals' knowledge and perceptions of second language programs for English language learners (ELLs) operating in their schools. An openended survey and in-depth interviews were used to examine elementary school principals' knowledge of the second language programs implemented at their schools. The survey asked principals about the strengths and challenges accompanying the program model currently implemented in their school(s), both anticipated and unanticipated of the program, and the staffing and professional development needed to improve the program. The interview asked similar questions to those on the survey and additional questions about the specific second language program(s) operating in their schools. Results indicated that principals had very limited knowledge about how the second language program(s) operating in their schools. Generally, principals attributed the success of their second language programs to the teachers in the program. The lack of knowledge about how to properly implement second language program is of concern since it is important for principals to be instructional leaders in their schools. Knowing how teachers should implement second language programs appropriately can assist principals in providing support to teachers as well as determining the type of training that their teachers may need in working more effectively with second language students.

Keywords: English learners; principals' perceptions; school leadership; second language programs 


\section{Investigación del Conocimiento y las Percepciones de los Directores de Programas de Segundas Lenguas para Estudiantes de Inglés}

Yolanda N. Padron

Texas $A \& M$ University
Hersh C. Waxman

Texas $A$ \& $M$ University

\section{Resumen}

El presente estudio examina el conocimiento y las percepciones de los directores de programas de segundas lenguas para estudiantes de inglés (ELLs) que operan en sus escuelas. Se emplearon una encuesta abierta y entrevistas profundas para examinar el conocimiento de los directores de escuelas de primaria sobre los programas de segunda lengua de sus escuelas. La encuesta preguntó a los directores acerca de las fortalezas y los desafíos que acompañan al modelo del programa implementado actualmente en sus escuelas, tanto previstos como imprevistos, y la dotación de personal y el desarrollo profesional necesario para mejorar el programa. La entrevista formuló preguntas similares a las de la encuesta y otras adicionales sobre los programas específicos de segundas lenguas implementados. Los resultados indicaron que los directores tenían un conocimiento muy limitado sobre cómo operaban los programas en sus escuelas. Por lo general, los directores atribuyeron el éxito de sus programas de segunda lengua a los maestros. La falta de conocimiento sobre cómo aplicar correctamente el programa de segunda lengua es motivo de preocupación, pues es importante para los directores ser líderes instructivos en sus escuelas. Conocer cómo deberían poner en práctica los profesores los programas de segunda lengua podría ayudar a los directores a prestar apoyo a los profesores así como determinar el tipo de formación necesaria para los profesores para trabajar más eficazmente con los estudiantes de segundo idioma.

Palabras clave: estudiantes de inglés; percepciones de los directores; liderazgo escolar; programas de segundo idioma 


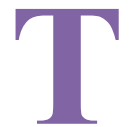

His study presented here examines 22 elementary school principals' knowledge of the bilingual/second language programs that are implemented at their schools that are located in a metropolitan school district located in the south central region of the United States and serves many English Language Learners (ELLs). As the number of ELLs continues to increase in many regions of the US, elementary school educators are faced with the critical challenge of providing them an appropriate education (Madsen \& Mabokela, 2014; Timberlake, Howell, \& Staight, 2011). While teachers must provide effective instruction for ELLs so that they are successful in learning English and academic content (Short \& Fitzsimmons, 2007), principals must also have the critical knowledge needed to support teachers in working with ELLs (Darling-Hammond, 2010; Graczewski, Knudson, \& Holtzman, 2009). Since principals in this district have the autonomy to choose and implement instructional programs, they need to have a strong knowledge base of effective instructional programs and practices for ELLs. However, Lesaux, Hastings, Kelley, Marietta, and Russ, (2010) found that administrators often lack the appropriate training needed for supporting instructional improvement. That is, principals may not have the basic knowledge of second language programs to be effective instructional leaders for second language teachers (Brown, 2004; Torres, 2006). Principals need to have an understanding of appropriate instructional practices for ELLs because earlier research has found that teachers of ELLs often feel that they do not have the skills required to successfully teach ELLs (Gándara, Maxwell-Jolly, \& Driscoll, 2005; Téllez \& Waxman, 2006). Research, for example, has found that less than one-third of U.S. teachers have received less than eight hours of professional development on strategies for teaching ELLs (Darling-Hammond, 2010). The lack of training for teachers necessitates that principals have the appropriate knowledge about second language programs so that they can support teachers in working with ELLs. The present study asserts that if bilingual/second language programs are to be effective in assisting children achieve academic success, then the school leadership must encourage and support the goals of the program. There are few studies, however, that have specifically examined the how knowledgeable principals are about the second language programs in their schools.

The role of the principal as an instructional leader is critical. Research, for example, has found that effective school leadership can have a strong 
impact on student success, particularly when principals take on an instructional leadership role such as supporting curricular implementation and understanding instructional strategies (Lesaux, et al., 2010; Marzano, Waters, \& McNulty, 2005). This is also true for the successful implementation of education programs for ELLs (Aguilar, 1979; Peterson \& Heywood, 2007). In addition, to the role that strong leadership plays in student success, the amount of support that teachers receive from principals plays a major role in whether teachers decide to stay in the profession (Ingersol1, 2001). In addition, principals play a key role in the professional development of second language teachers (Alford \& Niño, 2011). There is some limited evidence that suggests that principals who support their staff by providing staff development opportunities that focus on ELLs have been successful in implementing programs for ELLs in their schools (Garrett \& Morgan, 2002). Principals need to have an understanding of the appropriate implementation of the second language programs so that they can support their teachers in the implementation of second language programs and can also determine the type of professional development that teachers in their schools might need. Furthermore, principals may be in the position to provide input in implementing district policy in regards to educational programming of language minority students, having an understanding of what research says are best practices for ELLs may result in district-level changes.

Principals' knowledge and perceptions of how programs should be implemented is also important when implementing programs for ELLs because negative attitudes, prejudices, and misinformation about bilingual education/second language programs may lead to inappropriate practices (Alanis \& Rodriguez, 2008; Lindholm-Leary, 2001; Rodriguez, 2009). Considering the key role that principals play in the successful implementation of programs for ELLs and their potential impact on students' academic success and teacher retention, it is important to investigate principals' knowledge and perceptions of the second language programs that are being implemented in their schools.

\section{Purpose of the Study}

The purpose of the present study is to investigate principals' knowledge and perceptions of the second language programs that are delivered in their 
schools. That is, how knowledgeable are principals about the instructional programs that serve English Language Learners (ELLs) on their own school campus? In addition, it examines principals' perceptions of the how teachers and members of the community perceive the second language programs in their schools. The study addresses following questions: Are principals able to describe the basic instructional premises of the second language program(s) being implemented in their school? What do they perceive to be the strengths of these programs? And what do they perceive to be the weaknesses of these programs?

\section{Methods}

\section{Setting of School District}

The district is located in a metropolitan area in the south central region in the U.S. The school district encompassed 345 square miles and served 23,864 students in 2009-2010. The district's ethnic composition is as follows: 44.4\% Hispanic, 30.6\% White, 19.1\% African-American, 5.5\% Asian, and $0.3 \%$ Native American. Additionally, $47.56 \%$ of the students are classified as coming from economically disadvantaged families; $41.5 \%$ are at-risk; and $13.9 \%$ have limited English proficiency (PEIMS, 2010). Although there is a diversity of languages (approximately 40) spoken in the district, the majority of second language learners are Spanish-speakers.

\section{Sociolinguistic Context of the District}

The school district implements three different program models for teaching language minority students for whom English is not the primary language spoken at home. The three types of bilingual program models offered in the district included: Transitional bilingual, Dual Language, and ESL programs. The goal of the transitional bilingual program there is to transition students to English as quickly as possible. That is, in the transitional program the students' native language is used to support learning the second language and content areas. When the student achieves some proficiency in the second language, the native language is no longer used and the student is transitioned to an all-English classroom. This goal of transitional bilingual programs is considered subtractive in nature in that students are moved to 
learn English and little or no effort is made to maintain the native language. On the other hand, dual language programs are considered additive in that they promote bilingualism and biliteracy for students. These programs use the students' native language for content instruction as the students learn the second language. Research has found that students in DL programs can acquire high levels of proficiency in both their native and second language (Calderón \& Minaya-Rowe, 2003; Thomas \& Collier, 2012).

Dual Language programs have has their goal bilingualism and biliteracy, academic attainment, and positive cross-cultural attitudes and behaviors in all students (de Jong, 2002). In this program, native English speakers and speakers of another language (in this setting Spanish speakers) participate in the program and receive instruction in both languages. The dual language program implemented in this district is a TWI 90:10 model where all instruction occurs in the target language and oral language development in English in Kindergarten and first grade. This model increases the ratio of the majority language progressively throughout the program (Soltero, 2004).

Students in ESL programs typically speak a variety of languages, so instruction in the students' native language is not possible (Soltero, 2004). In this particular school district there were approximately 40 different languages and dialects spoken. ESL programs provide instruction to students using second language methodologies to teach academic content and language objectives. The goal of ESL programs is to provide each student with the English skills necessary to successfully function in the academic setting (Honigsfeld, 2009). The ESL program provided in the district mainstreamed ESL students in a program in which both academic content and language content objectives were taught by an ESL certified teacher. In the present study 14 of the schools had transitional programs, four schools had ESL programs and three schools offered dual language programs.

\section{Participants}

This study was conducted with 22 elementary school principals in the school district previously described. There were eight were males and fourteen females. The ethnic background is as follows: four African Americans (one male and three females); two Hispanic (males) and 16 Anglo (5 males and 11 females). Their years of experience as a principal ranged from 5-22 years; 
15 of the participants had 5-9 years of experience; 6 had 10-17 years of experience and one had 22 years of experience. Their experience in working with second language programs ranged from 3-33 years. The greater number of years of experience in working with second language programs is due to the fact that three of the principals had worked as a teacher in a second language program prior to becoming a principal.

\section{Instruments}

Two instruments were used in this study: a principal survey and an interview.

Principal Survey. Since extended responses to the questions were sought, the survey consisted of four open-ended questions that were developed by the researchers based on other surveys of principals (Grady \& Dwyer, 2014). The open-ended survey included the following questions related to the second language programs in their school:

1. What are the strengths of the second language program at your school/district?

2. What are the challenges in implementing the second language program at your school/district?

3. What have been some of the unanticipated outcomes in implementing the second language program at your school/district?

4. What changes would you like to see in the second language program at your school/district?

All elementary school principals in the school district whose school implemented second language programs were administered the survey during a staff development session. The surveys took approximately 20 minutes to complete. All responses were anonymous. The responses for each of the questions were read and then analyzed and coded. Several themes emerged from the responses to each of the questions.

Principal Interview. The 22 elementary school principals who completed the survey were interviewed approximately one month after completing the survey instrument. The in-depth interviews consisted of 20 questions and followed a semi-structured, interview protocol. The first part of the interview asked participants' demographic information such as the number of years each had been principal, the number of years each had been involved in LEP programs, and experiences with second language learning. 
The interview questions focused on the types of language programs that were available for second language students on the particular campus. The questions addressed the following aspects of their second language program: (a) strengths and weakness; (b) implementation challenges; (c) fidelity of implementation; (d) parents' attitudes toward the language program(s); (e) types of professional development that their teachers received and needed; and (f) staffing issues for the second language programs. In addition, all participants were provided with the opportunity to share any additional information or comments that they wanted to provide about their second language program: Are there any other comments that you would like to share with me about your second language programs?

After the principals completed the survey, a member of the second language district personnel informed them that they would be contacted to participate in this interview. A follow-up e-mail was sent to all the participants by the researcher asking for a convenient time to conduct the interview. All interviews were conducted by phone at a time chosen by the principal. Interviews took approximately 20 minutes to 45 minutes to complete and were completed within a two-week period. The difference in the length of time of the interviews is due to how much information a principal was willing to provide.

We analyzed the qualitative data collected in a multiple-phase process, beginning with reading and re-reading responses to each survey and interview question to become familiar with the data. During this process, we noted any sections deemed significant or meaningful in each response and assigned provisional codes to them. Because the primary focus of the study was the principal, we next conducted a cross-interview analysis (Patton, 2015) for each survey and interview question. We utilized a constant comparison method to label, sort, and arrange coded excerpts of answers from the different respondents into tentative categories (Merriam \& Tisdale, 2016; Seidman, 1998), using the interview protocols as a guide. Finally, we compared the tentative categories to each other, examined connections between and among them, and identified themes across the individual principals. 


\section{Results}

\section{Principal Survey Results}

Two prominent themes in principals' knowledge and perceptions of second language programs emerged across survey items in the data: (a) the key role of the high quality teachers in second language programs for ELLs and (b) the lack of clarity and consistency in programs for ELLs, especially at the school- and district-levels. Principals noted that teachers were the greatest strength in the existing programs. One principal, for example, wrote that "Dual language teachers are extremely strong," while another described bilingual teachers as being "among the best" in the district. They also stressed their teachers' commitment to their students: "Teachers with desire to do well by children," and "Teachers that are dedicated and will do what it takes to help students learn." Even though principals overwhelming described the high caliber of bilingual teachers, several comments suggested a tension in the perceived quality of bilingual teachers. Another principal noted that there was a "lack of good training" for bilingual teachers. Concerns about teacher training and certification related to working with special needs students were noted by several principals.

Another strength of their program that principals reported pertained to parents. That is, principals indicated that: "For the most part parental support is strong;" and that "Parents are supportive of the program." Not only did principals perceive the parents as supportive, but they also felt that "Students do well in Bilingual classrooms" and that students in second language programs: ".... scored well on state assessments" and are "Capable students."

While principals' comments related to second language teachers, parents and students were generally positive, the perceptions of the second language programs and the manner in which they were implemented across the district were less positive. Principals, for example, indicated that one of the most challenging aspects of implementing their second language programs was the lack of professional development for their second language teachers. Several principals wrote that there was: "Lack of good training" for all teachers in the second language program. For example, principals commented that staff development was needed "For new teachers; ESL teachers; "all" teachers in the DL (Dual Language) program and "Staff 
development on vocabulary building for the ESL children." In addition, some principals felt that additional training was needed for the second language district level personnel.

Principals also reported that it was particularly important to have more professional opportunities for their teachers because of the lack of structure of the second language programs across the district. Nearly every principal noted that the programs needed structure and consistency, both within individual schools and across schools in the district. One principal suggested that "A clear mission of how bilingual children should be taught needs to be established" and another asserted that "Full implementation of the program goals at campus level has been disjointed due to lack of (an) organized training model." Beyond simply noting the perceived challenges within the second language programs, principals noted the effect of this lack of clarity on both second language teachers and their EL students. Specifically, principals indicated, "regardless of a teacher's quality, a teacher who does not understand the specific program requirements (e.g., when to use the first language in a two-way program) may unintentionally affect students' academic and linguistic development." Some principals further reported, "Even teachers who sought out help (from the district office) may not find clear answers." Another principal wrote that there was "confusion about who is the primary decision-maker for the campus program - the district level staff, campus administrators, or lead ESL teacher/facilitators." The outcomes for students of a program that is implemented haphazardly or inconsistently were reflected in comments noted by several principals: "Some students are not proficient in any language" and "Spanish students are strong academically in Spanish but are transitioning into English more slowly than anticipated."

One of the most cited issues had to do with "Hiring qualified, experience staff." Principals indicated that: "Truly bilingual teachers are hard to find." They indicated that "Not being able to speak the child's language" was a reason why they often were not able to hire a teacher. As one principal reported: "Teachers unprepared for working with these children." Not only, was the lack of qualified teachers an issue in implementing the program, but principals reported that parents often signed waivers to keep their child from attending second language programs because they did not want to their child to leave their home school and attend a different school where the appropriate second language program that the child needed was 
offered. As one principals indicated: "Parents deny bilingual and accept ESL to keep student on a home campus or keep siblings together." Another principal reported the difficulty in explaining the benefits of bilingual education programs to parents: "Parents want their children speaking English quicker."

It is interesting to note that when principals were asked to provide suggestions for improving the second language programs in their schools the greatest numbers of responses related to changes that they would like to see in the district's second language program office. These are examples of the written responses: "Consistent vision from the district level," "Consistent implementation of district expectations," and "District to adapt a set philosophy, goal, and purpose of the Bilingual program."

Principals felt that they should have the opportunity to choose the type of second language program that is implemented on their campus. They indicated that one way to improve the implementation of second language programs in the district was to have the district allow the school "Campus to have option to select program" and that it should be the principals' decision whether there was an "Option of transitional bilingual program." One principal suggested: Maybe 1 DL-2 way program at 1 campus with a campus principal that truly believes and supports the program" while another principal stated to allow teachers the: Opportunity to incorporate best practices to be able to accommodate specific student needs. '”

Overall, the results from the open-ended surveys indicated that principals felt that the major strength of their second language programs was the teachers in their schools and that they have been successful with their students in terms of scores on high stakes tests. Another strength that principals cited was that parents were very supportive in the education of their children. Although principals indicated that the teachers were the main strength of the program, they also reported that teachers needed additional professional development. Since principals were not able to provide the instructional support that their teachers needed, they wanted teachers to have more and better professional development training so that they could better implement the various second language programs. In addition, principals felt that teacher professional development was important since there was a lack of clarity from the district second language office on the specifics of implementing second language programs, particularly dual language programs. As one principal indicated: "Teachers need clear expectations of 
what they should be doing when implementing programs" and "Commitment to carry out program as intended."

\section{Interview Results}

Data from interviews corroborated the survey findings and provided some additional insights to the responses that had been given in the survey. The same 22 elementary school level principals who completed the survey were interviewed. The interview began by asking principals information about their professional background. Nineteen of the principals did not had any formal learning experiences related to bilingual education nor second language learning in their academic preparation, while three of the principals indicated that they had some professional development in relation to bilingual and second language acquisition. These three principals had completed some coursework toward an ESL endorsement for their teaching certificate. These principals indicated that the coursework that they had received helped them to understand some of the issues related to learning through the child's first language. One of the principals had been a teacher before becoming a principal explained: "My experiences as a teacher working in bilingual programs with very good bilingual teachers has been invaluable to me as a principal."

The next set of questions asked the principals to describe the second language programs offered at their campus. Of the 22 principals interviewed, 20 could not provide specific information about the program implementation. For example, one principal's description of the program(s) provided in his school: "One way, two way, basically transitional." Another stated: "ESL, Dual Language-don't know if dual language. We modify (the program) so that students can be successful." Other principals focused on how the programs were staffed: "We divide the students equally (among the teachers). They are mainstreamed with an ESL certified teacher. Once every other week a bilingual specialist comes in to work with the students." Another principals whose school, according to him had a transitional program described the program as follows: "Teachers (in the program) do what they need to do."

The responses of two of the principals whose school implemented a dual language program were very different. These two principals were able to state the specific goals and objectives of the program. In addition, they were 
able to describe how the programs were being implemented in their schools. For example, one of the principals stated: "We have a dual language selfcontained program in grades PreK-5. This is a 90:10 program. Our goal is that this students will be bilingual and biliterate." This principal continued to explain in depth the complete daily schedule for the students and what language was used during a specific time and content area. There was an additional principal whose school was beginning to implement a dual language program. This principal was not sure that this was the best program for his school and explained that: "We have started this year to implement a dual language program, but the teachers do not like it." I am not sure that it is going to work for us." The interviews indicated that the principals that had a better of understanding of second language learning focused more on content learning rather than learning English (Hickman, \& García, 2014).

In terms of program "Weakness" and "Challenges" the most often cited weakness and challenge was staff development. Principals indicated that the teachers were not well prepared to teach in classes. Also, they explained that the school district had a new policy where they would only hire ESL certified teachers. This meant that the school district could mainstream second language students, since all the teachers were required to be ESL certified. This practice resulted in having teachers who were not prepared to work with second language students who were mainstreamed into an English classroom (Padrón, Waxman, Rollins, Alford, \& Franco-Fuenmayor, 2015). This is how the policy worked as described by one of the principals: "ESL classroom that is just like a normal classroom with an ESL teacher." This practice alleviated the problem of finding teachers that were ESL certified, although it did not deal with the issue of providing the truly qualified teachers that principals needed. One principal commented; "ESL certification by test is problematic since there is no training involved." Another principal further explained: "ESL teachers feel unprepared once certified. There is no follow up on how effective their instruction is." "Teachers need foundational trainings for ESL."

Similar to the survey results, a major challenge that principals discussed in the interview was the lack of support from the district on how to implement the various program types with fidelity. Two principals indicated that the program at their school was consistently implemented, but that across the district the programs were in general not consistently 
implemented. For example, a principal stated: "Training and procedures are often unclear and unsupported in terms of staffing and funding" and "There is a need to establish a clear mission of how bilingual children should be taught."

Not surprisingly, when asked about the types of changes that would be needed to continue to implement an effective second language program principals indicated their frustration with the leadership at the district level about second language programming stated the following: "Improved communication and leadership from district second language program office, materials (in Spanish and ESL), staff development for working with second language students (i.e., bilingual and ESL), appropriate guidelines for implementing second language programs."

The responses from the interviews give some insights about the principals' perceptions of their teachers. Principals stated that they had excellent teachers and gave their teachers the freedom to do what they felt was needed for each students. Although they indicated that the teachers in their second language programs were "strong;" they also indicated that there was a need for professional development in a variety of areas such as vocabulary building. As a matter of fact during the interview principals indicated that staff development was one of the most challenging aspects of implementing their program(s).

Principals also expressed frustration with being forced to implement a particular second language program. They preferred to be able to implement the program that they felt best fit their campus. Several of the principals indicated that it would be more beneficial to their students if the principal chose the program to be implemented at their schools because they knew their school needs best.

\section{Discussion}

Overall, the findings from the principal interviews and survey were very similar. For example, in both the interviews and surveys the principals indicated that teachers were the main strength of the second language programs. Although this finding appears to be very complimentary to teachers, it may be do the fact that since the principals do not know how to implement the program they have to rely on their teachers and as one principal said: "to do the right thing." In other words, this finding may be 
problematic because it implies that the principals perceive that the implementation of second language programs is the responsibility of the second language teacher (Brooks, Adams, \& Morita-Mullaney, 2010).

The findings from this study are similar to the few previous studies that have found that principals have limited knowledge about programs for second language students (Rong \& Brown, 2002; Hickman, \& García, 2014; Torres, 2006). Results from the interviews indicate that principals have various levels of knowledge of second language acquisition depending on their professional preparation and experiences related to second language programs. However, the majority of the principals in this study had little understanding of how the second language program in their school functions.

While it is admirable that principals reported trusting their teachers, not being able to determine the inappropriate implementation of second language programs can potentially damage the academic success of ELLs. Because of the variety of second language program models and the complexity of instructional program provided for ELLS, principals need focused professional development training that focuses on issues related to language learning and instruction so that they will be able to provide guidance and support to second language teachers, who often lack this type of training. Considering the positive impact that instructional leaders can have on classroom instructional practice, it is crucial that principals be better prepared to meet the need of the growing second language student population.

\section{Implications for Further Research}

There are a number of important areas that should be addressed in future research studies. First, we need to further examine the principal's role in the implementation of second language programs. The results from this study suggest that principals do not feel that it is their role to implement programs, so interviews with district-level administrators might actually reveal what their role in the process should be. Another important area that needs further investigation is the how principals perceive the instructional role of their second language teachers. It may be interesting to determine if principals view their teachers of ELLs as tutors, language teachers, or merely typical classroom teachers. 
Future studies should also attempt to conduct larger-scale studies that could determine whether there are any relationships or difference due to principal background characteristics (e.g., age, gender, ethnicity, and experience) and/or school context variables (e.g., high v. low-poverty schools, type of language program implemented). The present, exploratory study did not find any substantive differences due to principal background characteristics or school context variables, but additional larger-scale studies conducted in several different school districts may reveal some important relationships.

\section{Conclusions}

Principals need to play an active role in assuring that highly qualified teachers appropriately implement programs for second language students. In order to become more involved in the second language programs in their schools, they need to become more knowledgeable of issues related to appropriate instructional process for second language students. For second language programs to be effective and, more importantly, in order for ELLs to experience success at school, principals must be become knowledgeable and supportive of the goals and design of these programs. One important practice that has been found to effective in improving classroom instruction for ELLs is systematically observing teacher and student behaviors in the classroom (Padrón, Waxman, Rollins, Alford, \& Franco-Fuenmayor, 2015; Waxman, Padrón, Franco-Fuenmayor, \& Huang, 2009). The results from the present study suggest that principals are not really aware of what teachers of ELLs are doing in their classrooms, so systematically observing classrooms may be an important first step for them. The principals who participated in this study indicated that their teachers needed more professional development on how to support ELLs in their classrooms. It appears, however, that principals also need more professional development on research on effective programs and instructional practices for ELLS (Waxman \& Padrón, 2002; Waxman, Padrón, \& Garcia, 2007). The findings from this study suggest that principals need to become more knowledgeable on how to support their teachers to meet the needs of a growing student population and close the achievement gap between native English speakers and ELLs. 


\section{References}

Aguilar, J. V. (1979). The building principal's role in bilingual education program. Journal of Teacher Education, 30, 26-28. doi: 10.1177/002248717903000309

Alanis, I., \& Rodriguez, M. A. (2008). Sustaining a dual language immersion program: Features of success. Journal of Latinos \& Education, 7(4), 305-319. doi: 10.1080/15348430802143378

Alford, B. J., \& Niño, M. C. (2011). Leading academic achievement for English language learners: A guide for principals. Thousand Oaks, CA: Corwin. doi: 10.4135/9781483350318

Brooks, K., Adams, S., \& Morita-Mullaney, T. (2010). Creating inclusive communities for ELL students: Transforming school principals' perspectives. Theory into Practice, 49(2), 145-151. doi:

10.1080/00405841003641501

Brown, K. M. (2004). Leadership for social justice and equity: Evaluating a transformative framework and andragogy. Educational Administration Quarterly, 42(5), 700-745. doi: 10.1177/0013161X06290650

Calderón, M., \& Minaya-Rowe, L. (2003). Designing and implementing two-way Bilingual Programs. Thousand Oaks, CA: Corwin.

Darling-Hammond, L. (2010). The flat world and education: How America's commitment to equity will determine our future. New York: Teachers College Press.

de Jong, E. J. (2002). Effective bilingual education: From theory to academic achievement in a Two-Way bilingual program. Bilingual Research Journal, 26(1), 1-20. doi: 10.1080/15235882.2002.10668699

Gándara, P., Maxwell-Jolly, J., \& Driscoll, A. (2005). Listening to teachers of English Learners. Santa Cruz, CA: Center for the Future of Teaching and Learning. Retrieved May 8, 2009, from http://1mri.ucsb.edu.libezproxy.tamu.edu:2048/publications/05 listening-to-teachers.pdf

Garrett, J. E., \& Morgan, D. E. (2002). Celebrating diversity by educating all students: Elementary teacher and principal collaboration. Education, $123,268-275,333$. 
Graczewski, C., Knudson, J., \& Holtzman, D. J. (2009). Instructional leadership in practice: What does it look like, and what influence does it have? Journal of Education for Students Placed at Risk, 14(1), 72-96. doi: 10.1080/10824660802715460

Grady, M. W., \& Dwyer, L. M. (2014). The English language program for principals. Washington, DC: U.S. Department of Education, Institute for Education Sciences, National Center for Educational Evaluation and Regional Assistance, National Educational Laboratory Northeast \& Islands.

Hickman, P., \& García, S. (2014). Elementary principal leadership for equitable learning environments for diverse Latina/o students. NYS TESOL Journal, 1(2), 59-85.

Honigsfeld, A. (2009). ELL programs: Not one size fits all. Kappa Delta Pi Record, 45, 166-171. doi: 10.1080/00228958.2009.10516539

Ingersoll, R. M. (2001). Teacher turnover and teacher shortages: An organizational analysis. American Educational Research Journal, 38(3), 499-534. doi: 10.3102/00028312038003499

Lesaux, N. K., Hastings, M. E., Kelley, J. G., Marietta, S. H., \& Russ, J. M. (2010). Turning the page: Refocusing Massachusetts for reading success. Boston, MA: Strategies for Children. Available from http://www.strategiesforchildren.org/Publications/TurningThePageR eport.pdf

Lindholm-Leary, K. J. (2001). Dual language education. Bilingual education and bilingualism. New York: Multilingual Matters.

Madsen, J., \& Mabokela, R. (2014). Leadership challenges in addressing changing demographics in schools. NASSP Bulletin, 98, 75-96.

Marzano, R. J., Waters, T., \& McNulty, B. A. (2005). School leadership that works: From research to results. Alexandria, VA: Association for Supervision and Curriculum Development.

Merriam, S. B., \& Tisdell, E. J. (2016). Qualitative research: A guide to design and implementation ( $4^{\text {th }}$ ed.). San Francisco: John Wiley.

Padrón, Y. P., \& Waxman, H. C., Rollins, K. B., Alford, B. A., \& FrancoFuenmayor, S. (2015). Using classroom observations to examine classroom instruction for ELLs in elementary school classrooms. Journal of Bilingual Education Research and Instruction, 17(1), 77-93.

Patton, M. Q. (2015). Qualitative research and evaluation methods: Integrating theory and practice ( $4^{\text {th }} \mathrm{ed}$.). Thousand Oaks, CA: Sage 
Peterson, S., \& Heywood, D. (2007). Contributions of families' linguistic, social, and cultural capital to minority-language children's literacy: Parents', teachers' and principals' perspectives. Canadian Modern Language Review, 63, 517-538. doi: 10.3138/cmlr.63.4.517

Public Education Information Management System (PEIMS). (2010). Texas Education Agency: Austin, TX.

http://www.tea.state.tx.us/peims/standards/index.html

Rodriguez, M. A. (2009). Instructional leadership that supports two-way immersion programs. Soleado, Promising Practices from the Field, $1,8-9$.

Rong, X. L., \& Brown, F. (2002). Immigration and urban education in the new millennium: The diversity and the challenges. Education and Urban Society, 34(2), 123-133. doi: 10.1177/0013124502034002001

Seidman, I. E. (1998). Interviewing as qualitative research: A guide for researchers in education and the social sciences $\left(2^{\text {nd }}\right.$ ed.). New York: Teachers College Press.

Short, D. J., \& Fitzsimmons, S. (2007). Double the work: Challenges and solutions to acquiring language and academic literacy for adolescent English language learners. New York: Alliance for Excellent Education.

Soltero, S. W. (2004). Dual language: Teaching and learning in two languages. New York: Pearson.

The National Clearinghouse for English Language Acquisition and Language Instruction Education Programs (NCELA), (2007). www.ncela.gwu.edu/expert/fastfaq/4.html.

Téllez, K., \& Waxman, H. C. (2006). Preparing quality teachers for English Language Learners: An overview of the critical issues. In K. Téllez \& H. C. Waxman (Eds.), Improving educator quality for English Language Learners: Research, policies, and practices (pp. 1-22). Mahwah, NJ: Lawrence Erlbaum.

Timberlake, J. M., Howell, A. J., \& Staight, A. J. (2011). Trends in the suburbanization of racial/ethnic groups in U. S. metropolitan areas, 1970 to 2000. Urban Affairs Review, 47(2), 218-255. doi: $10.1177 / 1078087410389531$

Thomas, W. P., \& Collier, V. P. (2012). Dual language education for a transformed world. Albuquerque, NM: Dual Language Education of New Mexico/Fuente Press. 
Torres, N. L. (2006). Administrative support for English language learners: How the SIOP model empowers teachers, administrators, and English language learners. (Ph.D.), University of Connecticut, Storrs, CT. (UMI No. 3231250).

Waxman, H. C., \& Padrón, Y. N. (2002). Research-based teaching practices that improve the education of English language learners. In L. Minaya-Rowe (Ed.), Teacher training and effective pedagogy in the context of student diversity (pp. 3-38). Greenwich, CT: Information Age.

Waxman, H. C., Padrón, Y. N., Franco-Fuenmayor, S. E., \& Huang, S-Y L. (2009). Observing classroom instruction for ELLs from student, teacher, and classroom perspectives. Texas Association for Bilingual Education Journal, 11(1), 63-95.

Waxman, H. C., Padrón, Y. N., \& Garcia, A. (2007). Educational issues and effective practices for Hispanic students. In S. J. Paik \& H. J. Walberg (Eds.). Narrowing the achievement gap: Strategies for educating Latino, Black and Asian students (pp. 131-151). New York: Springer. doi: 10.1007/0-387-44611-7_8

Yolanda Padron is Professor of Educational Psychology at Texas A \& M University.

Contact Address: ypadron@tamu.edu

Hersh C. Waxman is Professor of Teaching, Learning, and Culture and Director of the Education Research Center at the College of Education and Human Development, at Texas A \& M University.

Contact Address: hwaxman@tamu.edu 